\title{
Information Technology and New Media Advertising - The Concept Model of Audience Beliefs and Behavior toward Digital Advertising
}

\section{Rizky Kertanegara ${ }^{1}$ and Ina Primasari ${ }^{2}$}

${ }^{1}$ Creative Media State Polytechnic

${ }^{2}$ Sebelas Maret University

\section{Abstract}

This paper reviews the literature on the development of information technology in the field of advertising and proposes a concept model of audience beliefs and behavior toward digital advertising. Basically, advertising is a medium of communication based on the model of one-to-many communications models. For that reason, digital advertising is changing how advertisers market their products and services.

Keywords: Active Audience, Beliefs and Behavior, Digital Advertising, Information

Corresponding Author: Rizky Kertanegara; email: rizkykertanegara@gmail.com

Received: 09 April 2017

Accepted: 17 May 2017

Published: 12 June 2017

Publishing services provided by Knowledge E

(c) Rizky Kertanegara and Ina Primasari. This article is distributed under the terms of the Creative Commons Attribution License, which permits unrestricted use and redistribution provided that the original author and source are credited.

Selection and Peer-review under the responsibility of the ICoSaPS Conference Committee.

\section{G OPEN ACCESS}

\section{Technology}

\section{Introduction}

Since the emergence of the Internet in Indonesia in the 90s, the patterns of production and consumption of society has shifted. Now, people are more likely to use e-mail than letters, read news on their smartphones, and browse online to find the data than going to the library. The internet has allowed people to connect and communicate faster, easier and cheaper. Advertising has also benefitted from this development of information and communication technology. Advertiser's products and services can be directly target specific audience.

This year, there are at least 88 million active Internet users, or about a third of the Indonesian population. Based on that number, 48 percent are Internet daily users, according to Indonesian Internet Service Provider Association (APIII). The average time spent on television consumers is just 2 hours 22 minutes. This is in contrast with the average time spent on the internet via PC or tablet, as much as 4 hours 42 minutes, and via mobile phone for 3 hours 33 minutes [2]. The main factor that led to the rapid growth of internet usage is the fast and stable network, and also supporting mobile devices and its application [8]. This growth will impact on the exposure of advertisements 
in both print and electronic media. Some advertisers believe that traditional media advertising is out-of-date and no longer effective in reaching the target consumer.

Magna Global Data show that in 2015 the total advertising expenditure in television, newspapers, outdoor, radio and magazines are stagnant and have even declined globally. On the contrary, total digital media advertising continues to rise and is expected to beat the total television advertising budget in 2017 (KataData, 2016). In addition, according to Global web index, social media advertising and online advertising have effectively increased brand awareness of a product or service. In Indonesia, the ratio of digital advertising expenditure reached 10 percent in 2016, and will increase to 25 percent in 2019 beating the France, Spain, Brazil and Argentina (www.marketeers.com, 2016).

The Ministry of Communications and Information Technology stated that 80 percent of internet users are teenagers aged 15 to 19 years [6]. Advertisers are thus focusing on the young people. The changes in information technology culture can also be associated with an active audience paradigm. This paradigm stated that audience are no longer passive in receive media messages in advertising, but do actively interpret the text media. This paper hence proposes a concept model of audience beliefs and behavior toward digital advertising.

\section{Literature Review}

Advertising is an integral part of the promotional mix. In this modern era, advertising production pattern has also shifted due to the presence of information technology. Initially, the pattern of production leads to mass, then segmented, and now fragmented advertising.

\subsection{New Media and Digital Advertising}

Advertising is one of the promotional mix elements designed to introduce, to persuade, and or to remind a product offering to the target audience. Messages in the ads can be delivered through various media, such as television, radio, and magazines. Internet presence provides several significant advantages over advertising activities. Some advantages are easy and quick access to information, communication is more interactive than through traditional media (television, radio, newspapers), the use of multimedia (image, voice, text and video) allows more creativity, unlimited access where everyone can access, quick feedback and significantly lower costs ([11]: 78-79).

The new media is a combination of personalized media experiences and global platform for the participation of creating its own content. This indicates that the user has access to a two-way communication infrastructure. Two characteristic of this new 
medium is content distribution which is controlled by the user and the collection of accurate data about what they're watching, doing and creating. The combination of these two things can create a unique media environment, a platform that connects media providers and media seekers. Media providers are the ones who develop the creation of content created by the user (user-generated content), allowing advertisers to promote their products or services as media seekers. Internet, then, became the new media communications platform so that the content can be delivered to various devices ([1]: 284).

The presence of this new medium led to a dichotomy with existing media, which is then referred to traditional media. Some researchers claim that the traditional media is the medium the message connected with entertainment, while the new media is a message-based information medium This resulted in media advertising can be divided into offline and online advertising. Not much different from advertisements in traditional media, they see internet advertising as a format that contains commercial content that is paid for by sponsors, designed for an audience, delivered through video, print, audio, graphics or animations ([7]: 297). The advertisements contained in websites such as Banner ads, Skyscrapers, Pop-Ups, Pop-behinds, mini-sites, and Superstitials are visual-based internet advertising with a different experience.

Based on the above explanation, it is not surprising that today new media is seen as a very powerful advertising medium. However, it should be understood that, the character of the audience remains the same. They will click it when they are interested in the ads. On the contrary, they will ignore the unattractive ads.

\subsection{Digital Media Audience}

Basically, the audience in digital media is the same audience with targeted advertisers in traditional media. The presence of information technology also results in the changes of media consumption patterns. Shifting consumption is of course supported by the device and infrastructure which is increasingly inadequate. Currently, audience can access all the information they need in just one cell phone screen. They adapt to the technology quickly, specifically young people coming from the millennial generation.

The changes in behavior patterns of digital media can be seen from an active audience's perspective. Their activeness in finding the desired information requires advertisers to adapt to attract their attention. Communication is no longer running in one direction, but there are opportunities for two-way communication. So even with the communication message in the ads, advertisers can no longer say 'my product is good for you', but 'what product you need'. 
Referring to the theory of an audience, the theory of Uses and Gratification is relevant to describe the behavior of accessing this digital advertising. Uses and Gratification is a theory focusing on how individuals use the media and the needs sought from such use ([3]: 247). Furthermore, [5] gave five basic assumptions of the model Uses and Gratification: the audience is active and use media-oriented objectives; the initiative to connect the fulfillment of the needs of the medium of choice is in the hands the audience; the media compete with other sources of meet the needs of the audience; the audience increasingly aware of the use of media, interests, and motives; and each individual has a distinct meaning construction of the media of their choice ([3]: 258).

Hollis [4], in his research described the patterns of behavior of individuals when looking at digital advertising. Hollis stated that individuals learn and respond to different stimuli. Their knowledge and understanding influences how they interpret advertising messages. Based on these assumptions, Hollis categorized the four patterns of consumer behavior when consuming messages in advertising, the Active/Positive showing the interest behavior, Passive/Positive for the tranquility behavior, Active/Negative showing the dislike behavior, and Passive/Negative for ignorant behavior ([10]: 86). Hollis concluded that the role and involvement of memory, in the future, prove to be more important in achieving the long-term effects compared to short-term predictions of the effects of sales. Indicators of frequency, desire and involvement are useful to understand the role that the Internet may be an effective role in the ads.

Some studies were also conducted in Indonesia to determine how the internet user behavior patterns when viewing the ads. In [12], Sulistyo, in his research with 245 young people on the effect of confidence-in-the attitude toward the website advertising on user behavior, stated that Internet users have belief value that the advertisement on the website is an irritating factor, especially because its number is too many [12]. Therefore, Internet users will as much as possibly avoid the ads appearing like their behavior when accessing traditional media. Even so, the internet ads also have other significantly positive beliefs, like information and entertainment ([7]: 299).

Another research was conducted by [9] on the behavior of avoiding advertising on the internet with students at the University of Atma Jaya Yogyakarta. The result showed that the factors of perceived goal impediment, perceived ads clutter, prior negative experiences contribute to the avoidance of advertising on the Internet [9]. These three factors are the negative aspects in view of digital advertising coming from [3] study, entitled Why Do People Avoid Advertising on the Internet. Factors perceived impediment goal consists of distraction, disruption, and search hindrance. Then, factor of perceived ads clutter consists of irritation, exclusiveness, and excessiveness. Finally, 


Audience Beliefs toward Digital Ads
Positive Knowledge
1. Introducing/Informing
2. Persuading
3. Reminding
4. Entertaining
Negative Experiences
1. Impediment
2. Clutter
3. Prior Experiences

\section{Audience Behavior toward Digital Ads}

Positive

1. Positive-Active

2. Positive-Passive

Negative

1. Negative-Active

2. Negative-Passive

TABLE 1: Digital advertising map.

the factor of prior negative experiences consists of dissatisfaction, perceived lack of utility, and perceived lack of incentive.

The studies conducted on audience beliefs and behavior in interacting with digital advertising, the researchers summarized in Table 1.

\section{Conclusion}

The development in information technology makes some changes in all fields, including advertising. The presence of information technology enables the advertisers to provide a new experience to their target audience. However, this cultural change should also notice the audience beliefs and behavior, dominated by young people. Therefore, all stakeholders require an understanding of their audience to meet the goal of promotion of a product or service.

\section{References}

[1] O. M. Akhagba, "New Media Technologies and Advertising Practice in Nigeria," Estudos em Comunicação, pp. 277-308, 2014.

[2] A. M. Damar, (2016, February 14). tekno liputan 6. Retrieved September 4, 2016, from tekno.liputan 6.com: http://tekno.liputan6.com/read/2435997/3-faktamengejutkan-pengguna-internet-di-indonesia.

[3] C. H. Cho and H. J. Cheon, "Why do people avoid advertising on the internet?" in Journal of advertising, vol. 33, pp. 89-97, 2004, J. Baran, S., \& Davis, D. K. (2000). Mass Communication Theory: Foundations, Ferment, and Future (2nd ed.). Belmont: Wadsworth.

[4] N. S. Hollis, "Like it or not, liking is not enough," Journal of Advertising Research, vol. 35, no. 5, p. 17, 1995. 
[5] E. Katz, J. Blumer, and M. Gurevitch, The Uses communications, The Uses communications, 1974.

[6] Kemkominfo, (2014, Mei 8). Retrieved September 10, 2016, from kominfo.go.id: https://kominfo.go.id/content/detail/3980/kemkominfo-pengguna-internet-diindonesia-capai-82-juta/o/berita_satker.

[7] A. B. Mahmoud, "Syrian consumers: Beliefs, attitudes, and behavioral responses to internet advertising," Business: Theory and Practice, vol. 14, no. 4, pp. 297-307, 2013.

[8] A. Maulana, (2016, February 22). Retrieved September 4, 2016, from CNN Indonesia: http://www.cnnindonesia.com/teknologi/20160222155236-213-112610/penggunainternet-indonesia-tumbuh-berkat-smartphone/.

[9] D. C. Putra and F. A. Herawati, Pengaruh Perceived Goal Impediment, Perceived Ad Cluter, Prior Negative Experiences, terhadap Perilaku Pengguna Internet Untuk Menghindari Iklan di Internet. Daerah Istimewa.

[10] A. Racnhhod, "Advertising into the Next Millenium," International Journal of Advertising, pp. 85-103, 1998.

[11] A. Stojkovic, "Advertising and Promotion on the Internet," FACTA UNIVERSITATIS Series: Economics and Organization, vol. 10, no. 1, pp. 77-87, 2013.

[12] E. D. Sulistyo, (2015). Pengaruh Faktor Kepercayaan Terhadap Attitude toward Website Advertising dan Dampaknya Terhadap Perilaku Pengguna. Bandung, Jawa Barat, Indonesia: Universitas Telkom. 